\title{
The distribution of rare earth, precious metal and other trace elements in Recent and fossil deep-sea manganese nodules
}

\author{
G. P. Glasby, ${ }^{1}$ R. R. Keays, ${ }^{2}$ and P. C. Rankin ${ }^{3}$ \\ New Zealand Oceanographic Institute, D.S.I.R., P.O. Box 12-346, Wellington, New Zealand, ${ }^{1}$ \\ Department of Geology, University of Melbourne, Victoria, Australia, ${ }^{2}$ and \\ Soil Bureau, D.S.I.R., Lower Hutt, New Zealand. ${ }^{3}$
}

(Received March 1, 1978; accepted in revised form August 22, 1978)

\begin{abstract}
Four deep-sea manganese nodules and one fossil nodule from Timor have been analysed for 45 elements (major elements, rare earths and precious metals) by X-ray fluorescence, spark source mass spectrometry and neutron activation analysis. Co-existing sediments from two nodule sites in the Southwestern Pacific Basin have also been analysed. Differences in nodule composition are apparent, particularly for the Timor nodule. The trace metal compositions of this nodule, however, reveals it to be a typical deep-sea nodule, although some element redistribution has clearly taken place since exposure of the nodule on land. The distribution of a number of elements including $\mathrm{Tl}, \mathrm{Ir}, \mathrm{Pd}, \mathrm{Au}$ and the rare earth elements between deep-sea nodules and their associated sediments appears to be dependent on a number of factors including the major element composition of the nodule (e.g. dilution by the silicate phase of the nodule), the differing stability of various element complexes in seawater, and the influence of differences in redox states on complex stability. $\mathrm{Au}$ and $\mathrm{Si}$, on the other hand, are positively correlated in nodules and sediments possibly because they have a common source, either submarine detritus or basalt-seawater interaction. The rare earth contents of the sediments from the N.E. sector of the Southwestern Pacific Basin are high compared with previous determinations of rare earths in marine sediments and show no evidence of $\mathrm{Ce}$ depletion relative to $\mathrm{La}$ on a shale-normalised basis. These high contents reflect the well oxidised conditions and low sedimentation rates of this environment.
\end{abstract}

\section{INTRODUCTION}

Although the distribution of trace elements, and in particular the rare earth elements, in marine manganese nodules has received considerable attention (e.g. HerrmanN 1970; PIPER 1972, 1973, 1974a, b; CROCKET et al. 1973; GLASBY 1973, 1975; VolKov and Fomina 1973; BALASHOV et al. 1974; SHIMA 1974; FleET 1975; Masuda and Nagasawa 1975; Sugimura et al. 1975; Sugimura 1977; Rankin and GlaSbY in press), the time consuming nature of the analytical techniques has resulted in only a limited number of analyses being available. Consequently, there is little consensus as to the mode of incorporation of trace elements in manganese nodules.

In this paper, we report the results of the analysis of four deep-sea manganese nodules for 45 elements using spark source mass spectrometry, neutron activation analysis and X-ray fluorescence spectroscopy. The major and trace element data are compared with those obtained from a fossil manganese nodule from Timor, believed to have been formed in a deep-sea environment. In addition, co-existing sediments from two sites in the Southwestern Pacific Basin have been analysed in order to show the relationship between the distribution of trace elements in deep-sea manganese nodules and their underlying sediments.

\section{SAMPle Location and Description}

Five manganese nodules from a range of deep-sea and fossil environments were selected for this study. Summaries of sample locations, sample descritpions, associated sediment types, nodule mineralogy and previous element analyses have been given by JOHNSTON and GLASBY (1978, Table 1). An account of the iron oxide mineralogy of the nodules has also been presented by JoHnSton and Glasby (1978).

Nodule samples G994 and G1004c were col- 


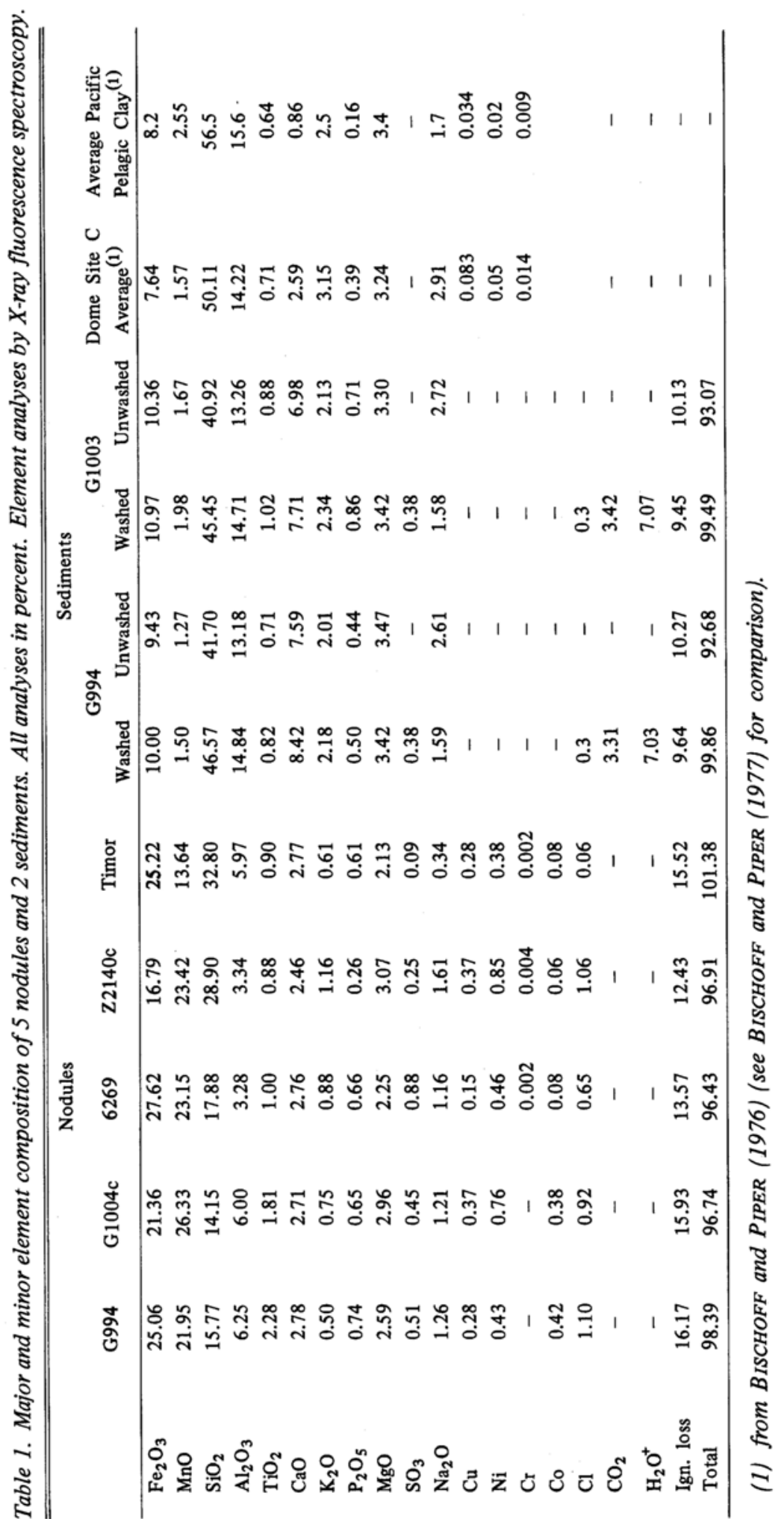


lected in the N.E. sector of the Southwestern Pacific Basin in the vicinity of Rarotonga during the cruise of R.V. Tangaroa in May 1974 (see MEYlAn et al., 1975; BÄCKER et al., 1976). Both sites are characterised by high nodule densities and greyish brown clay (5YR 3/2) sediments. A sediment sample from Stn G994 was analysed. Because no sediment was collected at Stn G1004c, sediment from Stn G1003, $92 \mathrm{~km}$ away, was analysed instead. Although both sediments are pelagic clays, they contain significant quantities of carbonate (Table 1).

Nodule sample 6269 was collected on the western flanks of the Carlsberg Ridge, Indian Ocean, during the cruise of the R.R.S. Discovery in 1967 (GlasBY et al., 1974). The dominant sediment type is globigerina ooze.

Sample Z2140 was collected at Stn 39 during cruise 36 of U.S.N.S. Eltanin in November 1969 (GlasbY, 1972a). The haul consisted mainly of nodules showing a wide range of morphologies and containing highly weathered volcanic cores. Manganese crustal thickness was generally of the order of $1 \mathrm{~mm}$. Glacial erratics also occurred as nodule nucleii. No sediment was recovered at this station.

The fossil manganese nodule from western Timor occurs on the Bobonaro Scaly Clay olistostrome (AudLEY-Charles, 1972). It is believed to have formed during the Cretaceous in a deep-sea environment on red clay and uplifted during the Miocene (MARGolis et al., 1978).

\section{Analytical Techniques}

Samples were prepared for analysis by grinding the material finely with a pestle in a porcelain mortar. Bulk samples were used for the two sediment samples and for nodule samples G994, G1004c and 6269. For Z2140, where the nodules had only a thin coating of manganese oxide around a nucleus of other material, hand picking of the outer crust was necessary. The fossil Timor nodule contained a hard, inner volcanic core which was removed during sample preparation.

No attempt was made in this study to investigate variations in composition between nodules from the same site or within individual nodules (e.g. RAAB, 1972).

The sediment samples contained approximately eight percent water-soluble salts. The samples were analysed after being washed in distilled water for 24 hours. For comparison unwashed sediment samples were also analysed for major elements (see Table 1).

1. X-ray fluorescence analysis $\mathrm{Fe}, \mathrm{Mn}, \mathrm{Si}$, $\mathrm{Al}, \mathrm{Ti}, \mathrm{Ca}, \mathrm{K}, \mathrm{P}, \mathrm{Mg}, \mathrm{S}$ were determined at the University of Melbourne in fused discs with a Siements XRF spectrometer using the method described by NORRISH and HUTTON (1969) and Thomas and HaukKa (1978). $\mathrm{Na}$ and $\mathrm{Cl}$ were also determined by XRF but in pressed powder discs. The samples were subsequently reanalysed at Soil Bureau, D.S.I.R., and concordant results were obtained.

2. Neutron activation analysis $\mathrm{Pd}, \mathrm{Au}, \mathrm{Ir}$, $\mathrm{Tl}, \mathrm{Cr}$ and $\mathrm{Co}$ were determined by a neutron activation analysis scheme modified from that of CROCKET et al. (1968) and KeAYs et al. (1974). The accuracy of the data is within $\pm 15 \%$; results by this method are compared with published data by SHAw et al. (1976). Re was also determined by neutron activation analysis using a method described by LOVERING and BUTTERFIELD (1970).

3. Spark source mass spectrometry The samples were mixed with an equal weight of ultra pure graphite containing $500 \mathrm{ppm}$ lutetium oxide as an internal standard. The concentration of 24 elements, including the rare earth elements, were determined. Details of the analytical technique are reported in RANKIN and CHILDS (1976). The mass spectrometric data is considered to have a precision of $\pm 15 \%$ (based on repeat analyses of the USGS standard BCR1).

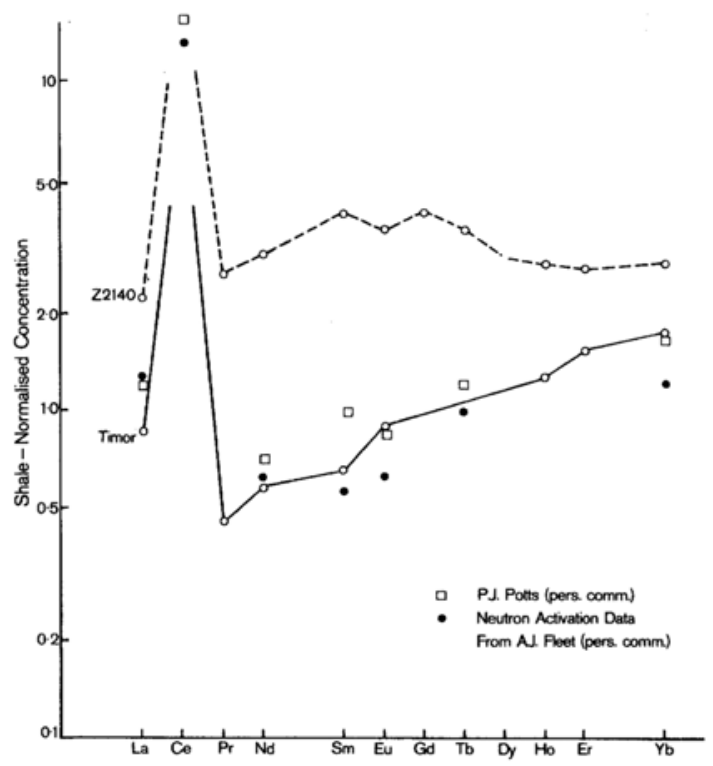

Fig. 1-a. 


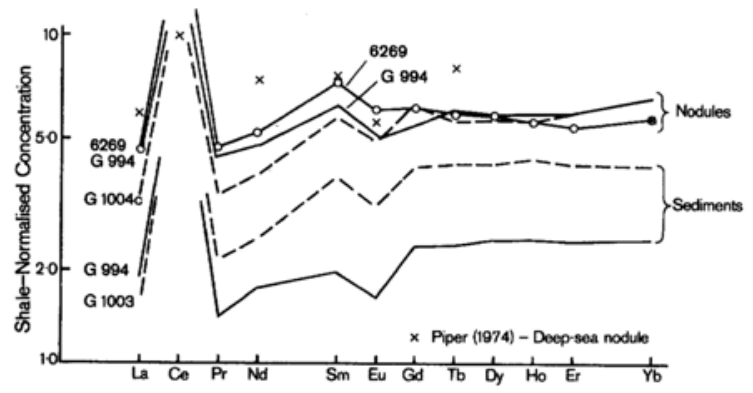

Fig. 1-b.

Fig. 1. Shale-normalised rare earth data for 5 marine nodules and 2 sediments. Shale data taken from HASKIN and SCHмiтT (1967). Data supplied by P. J. PоттS (Open University) are neutron activation analyses of a replicate sample of the Timor nodule analysed for this paper by mass spectrometry. Data supplied by A.J.

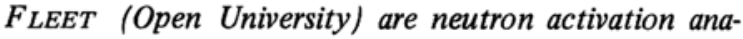
lyses of a second Timor nodule from the Bobonaro Scaly clay olistostrome collected independently from the nodule described here.

(The fossil Timor nodule was also analysed for some rare earth elements by neutron activation analysis (P. J. PoTts, pers. comm.). These were obtained to provide an assessment of the rare earth element data obtained by the spark source mass spectrometric technique; see Fig. 1). 4. Other analyses $\mathrm{Cu}$ and $\mathrm{Ni}$ were measured using a Varian Techtron (model AA-3) atomic adsorption spectrometer.

Whole sample $\mathrm{H}_{2} \mathrm{O}^{+}$was determined by heating the dried $\left(110^{\circ} \mathrm{C}\right)$ samples at $1,200^{\circ} \mathrm{C}$ in an oxygen stream and absorbing the liberated $\mathrm{H}_{2} \mathrm{O}$ onto magnesium perchlorate. Total $\mathrm{CO}_{2}$ measurements were made by the Leco gasometric technique.

\section{RESULTS}

\section{A. Nodules}

Major and minor element chemistry The similarities in the trace element chemistry of nodules G994 and G1004c from the Southwestern Pacific Basin (Table 2) are probably a reflection of the similarities in their major element compositions (Table 1). Most analyses lie within $15 \%$ of each other which represents good agreement considering the sampling problems involved in the analysis of manganese nodules. The major element data are similar to those in sample 6269. By contrast, sample Z2140 contains up to a factor of two less of a range of trace elements, although $\mathrm{Cs}$ is higher in this sample. Although the reasons for the difference in major element composition of Z2140 from the other three deep-sea nodules are not understood, it may in part be related to the higher content of silicate minerals in the sample (possibly due to inclusion of nucleus material during sample preparation, as revealed by higher concentration of $\mathrm{SiO}_{2}$, although $\mathrm{Al}_{2} \mathrm{O}_{3}$ is lower in this sample). Cs would be associated with the silicate phases and this is at a higher concentration in sample Z2140. Inclusion of extraneous silicate material would have the effect of lowering relatively the contents of authigenic elements in the sample.

The fossil Timor nodule shows a number of differences in composition from the deep-sea nodules. In particular, it has significantly higher contents of $\mathrm{Th}, \mathrm{Pb}$ and $\mathrm{Hf}$ and lower contents of $U$ and $Y$. These differences may reflect in part diagenetic changes due to weathering on land (c.f. MARGOLIS et al. 1978; JoHNSTON and GLASBY, 1978). The overall composition of the Timor nodule reveals it to be of deep-sea origin.

Rare earth elements The results presented in Table 2 indicate a close similarity in absolute rare earth abundances in nodules from the Southwestern Pacific. Basin (G994 and G1004c), where red clays form the dominant sediment type, and the nodule from the Carlsberg Ridge, Indian Ocean (6269), where globigerina ooze is the dominant sediment. Sample Z2140 (Indian-Antarctic Ridge) is up to a factor of two lower in concentration of individual rare earths while the fossil Timor nodule is a factor of two to seven lower in concentration of rare earth elements compared to nodules G994 and G1004c.

The concentrations of the rare earth elements agree well with those obtained by previous authors (e.g. VolKov and Fomina 1973; PIPER 1974a).

Figure 1 shows the shale-normalised rare earth abundance patterns of five manganese nodules obtained following the method of RANKIN and CHILDS (1976). The data for the average deep-sea nodule of PIPER (1974a, b) are plotted for comparison. The 4 deep-sea nodules (G994, G1004c, 6269 and Z2140) show similar trends. Cerium exhibits its well known enrichment relative to the neighbouring rare earth elements, reflecting its oxidation in nodules to its tetravalent state (GoldBERG et al. 1963; GLASBY 1973). The rare earth element data are also 
Table 2. Trace element composition of 5 marine nodules and 2 sediments. All analyses in ppm, except where otherwise stated.

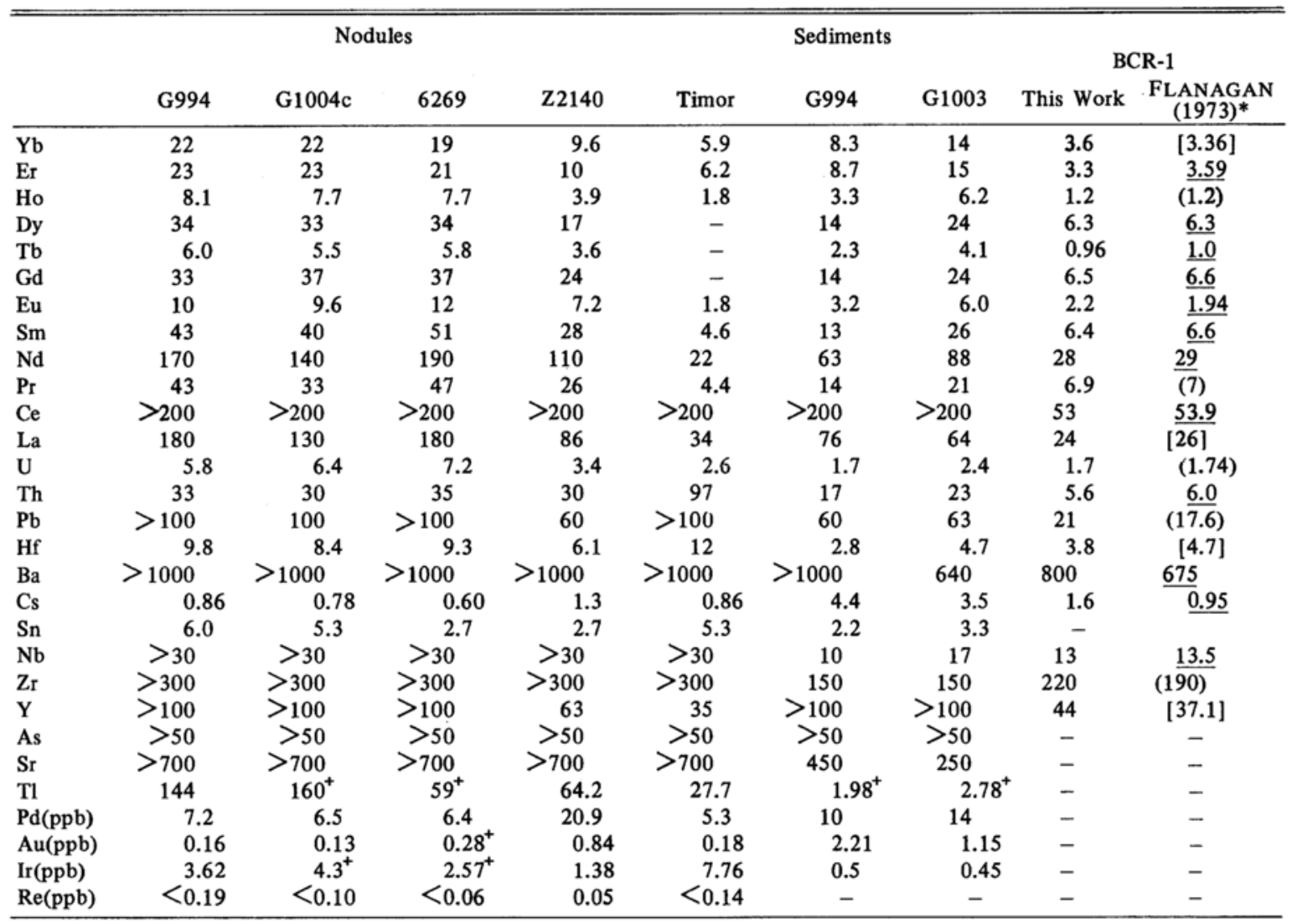

* I I = average; $($ ) = magnitude; $=$ recommended .

+ Duplicate analyses.

plotted relative to the rare earth data for seawater (GOLDBERG 1965) in Fig. 2. This distribution pattern is similar to that observed by Glasby (1973) and PIPER (1974a), i.e. with the exception of $\mathrm{Ce}$, there is a decrease in rare earth content relative to seawater with increasing atomic number.

The neutron activation rare earth data obtained for the fossil Timor nodule (P. J. PotTs, pers. comm.), while differing in absolute concentration from the mass spectrometric data, show a similar distribution pattern relative to shale (Fig. 1). Also included in Fig. 1 are data from A. J. FLEET (pers. comm.) for another sample of a fossil Timor nodule.

Precious metals Analytical results for $\mathrm{Pd}, \mathrm{Au}$ and $\mathrm{Ir}$ are presented in Table 2 and are compared with published data for hydrogenous nodules in Table 3. Although the averages for the manganese nodules for $\mathrm{Au}$ and Ir are con-

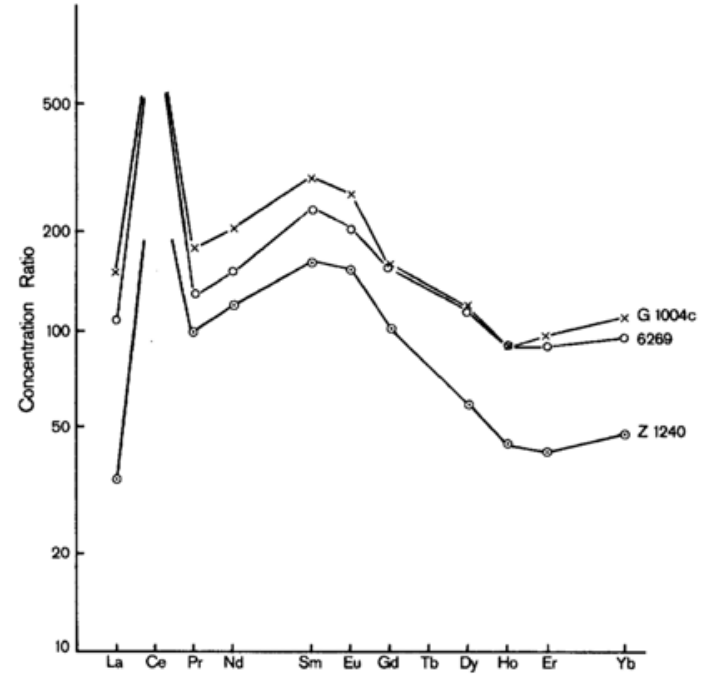

Fig. 2. Rare earth element distribution in nodules relative to mean abundance in seawater (GOLDBERG 1965). Ordinate scale should be multiplied by $10^{6}$. Note that there are considerable differences in the rare earth concentrations of seawater reported by GOLDBERG (1965) and PIPER (1974a) (see also MARTIN et al. 1976). 
Table 3. Comparison of precious metal data for marine nodules and sediments. All analyses in ppb.

\begin{tabular}{|c|c|c|c|}
\hline \multicolumn{4}{|c|}{ Deep-sea hydrogenous manganese nodules } \\
\hline Ir & Pd & $\mathrm{Au}$ & Reference \\
\hline $\begin{array}{l}9.5(16)^{*} \\
0.9-23.1^{+}\end{array}$ & $\begin{array}{l}5.3(19) \\
0.24-9.25\end{array}$ & $\begin{array}{l}2.9(19) \\
0.21-8.28\end{array}$ & HARRISS et al. (1968) \\
\hline $7.8(1)$ & - & $0.36(1)$ & KEAYS and SCOTT (1976) \\
\hline $\begin{array}{l}2.97(4) \\
1.38-4.31\end{array}$ & $\begin{array}{l}6.7(3) \\
6.4-7.2\end{array}$ & $\begin{array}{l}0.35(4) \\
0.13-0.84\end{array}$ & This work \\
\hline $7.41(21)$ & $5.49(22)$ & $2.37(24)$ & Grand Average \\
\hline \multicolumn{4}{|c|}{ Deep-sea sediments } \\
\hline $\begin{array}{l}0.35(3) \\
0.15-0.47\end{array}$ & $\begin{array}{l}4.5(21) \\
0.7-13.3\end{array}$ & $\begin{array}{l}2.7(21) \\
0.64-5.6\end{array}$ & CROCKET et al. (1973) \\
\hline $0.21(21)$ & - & - & BARKER and ANDERS (1968) \\
\hline $0.47(2)$ & $12.0(2)$ & $1.68(2)$ & This work \\
\hline $0.25(26)$ & $5.15(23)$ & $2.61(23)$ & Grand Average \\
\hline \multicolumn{4}{|c|}{ Fresh water manganese concretions } \\
\hline$<0.1$ & $0.045(2)$ & $0.38(2)$ & HARRISS et al. (1968) \\
\hline
\end{tabular}

* Number of analyses in arithmetic mean given in parentheses.

+ Range of values.

siderably lower than those of HARRISs et al. (1968), the data for the 3 precious metals fall within the range of concentrations observed by HARRISs et al. (1968). The results for Pd, Au and $\mathrm{Ir}$ in the deep-sea nodules are approximately three orders of magnitude lower than those previously reported for Hawaiian manganese crusts (ANON 1974) and this suggests that these previous analyses for the Hawaiian crusts, with their economic implications, are in error. This has been confirmed by J. L. BISCHOFF (pers. comm.). Similarly, analyses of $\mathrm{Pd}$ and $\mathrm{Au}$ in nodules reported by RANKAMA and SAHAMA (1950, pp. 694 and 707) and by SHILO et al. (1977) are much too high (see also NoAKEs and JoNES 1975, p. 1102 for comments on Pt values). The precious metal concentrations in the fossil Timor nodule confirm that it was of deep-sea origin as suggested by MARGOLIS et al. (1978). The nodules have much higher Pd and Ir contents than freshwater manganese nodules (HARRISS et al. 1968) and their Ir contents are greater than most crustal rocks (CROCKET 1969; Crocket and TERUTA 1977).

The $\mathrm{Au}$ contents of the nodules correlate positively and the Ir contents negatively with their silica contents (Figs. 6 and 7).

Thallium The average $\mathrm{Tl}$ contnet of the 4 deep-sea nodules (106 ppm) agrees well with the average value $(100 \mathrm{ppm})$ reported by $\mathrm{DE}$ Albuquerque and Shaw (1972). The Tl content of the nodules decreases with increasing silica content. The two nodules from the Southwestern Pacific Basin (G994 and G1004c) have the lowest $\mathrm{SiO}_{2}$ contents and the highest $\mathrm{Tl}$ concentrations.

\section{B. Sediments}

In an attempt to establish the relationship of the composition of manganese nodules to that of the underlying sediment, two sediment samples (G994 and G1003) from the Southwestern Pacific Basin were analysed. As noted earlier, because of the proximity of Stn G1003 to Stn G1004C, nodules from G1004c and sediment from G1003 were regarded as being from the same station.

The two sediment samples are similar in composition (Tables 1, 2), although G1003 is slightly higher in all elements except $\mathrm{Si}, \mathrm{Ca}, \mathrm{Mg}$, $\mathrm{La}, \mathrm{Sr}, \mathrm{Cs}, \mathrm{Ba}$ and $\mathrm{Au}$. The higher contents of $\mathrm{Si}, \mathrm{Sr}$ and $\mathrm{Ba}$ in $\mathrm{G} 994$ may be related to higher contents of terrigenous material derived from the New Zealand landmass as this sample was taken from a station closer to New Zealand than G1003 (see MEYLAN et al. 1975; BäCKER et al. 1976 for discussions). Dilution by terrigenous material would have the effect of lowering the relative concentrations of elements derived from 
other sources and could therefore account for their lower observed value in sample G994. The reasons for the higher values of $\mathrm{La}$ and $\mathrm{Au}$ are not known. The sediments are similar in composition to previously reported averages for DOMES Site $\mathrm{C}$ in the Northeast Equatorial Pacific and of the whole Pacific (BISCHOFF and PIPER 1976). Minor differences that are observed are probably due to differences in relative amounts of silicate, carbonate and authigenic phases. For G994 and G1003 sediments, the $\mathrm{Au}$ values are similar to those reported for sediments from the flanks of the East Pacific Rise (Crocket et al. 1973; PIPER and GraEF 1974). The rare earth element concentrations are, however, higher than those in a number of abyssal marine and other sediments (HASKIN and GeHL 1962; WILDEMAN and HASKIN 1965; HASKIN et al. 1966; SHIMOKAWA et al. 1972; VOLKOV and FoMina 1973; FleEt and KeMPE 1974; PIPER 1974b; PIPER and Graef 1974; PIPER et al. 1975; FleEt 1977; HeIN et al. In press; MELGUEN et al. In press) as well as in marine basalts (Masuda and Nagasawa 1975; Fleet et al. 1976; THOMPSON et al. 1978), although the La concentrations are lower than those reported in previous spectrographic analyses of some marine clays (Young 1954; GoldBERG and ArrheniUs 1958; El WAKEel and RILEY 1961) (see however, Dymond et al. 1973, 1977). The high rare earth contents of the G994 and G1003 sediments therefore probably reflect the well oxidised nature of these sediments (to be published elsewhere). Further, there appears to be no evidence of $\mathrm{Ce}$ depletion relative to $\mathrm{La}$ on a shale-normalised basis in these sediments as noted by PIPER (1974b) for other marine sediments suggesting that Ce depletion is not a characteristics of all marine sediments, particularly ones from well oxidised, low sedimentation rate environments such as encountered in the N.E. sector of the Southwestern Pacific Basin.

\section{Element enrichment sequence}

For Stn G994 the enrichment sequence of elements in nodules relative to the surrounding sediment is as follows (enrichment values given in parentheses):

$\mathrm{Tl}(73)>\mathrm{Mn}(17)>\operatorname{Ir}(7.4)>\mathrm{Hf}(3.5)>\mathrm{U}(3.4)$ $>\mathrm{Ti}(3.2)>\mathrm{Fe}(2.7)=\mathrm{Sn}(2.7)>\mathrm{Yb}(2.6)$

$>\mathrm{La}(2.4)>\mathrm{Th}(1.9)>\mathrm{P}(1.7)>\mathrm{Mg}(0.75)$

$>\mathrm{Pd}(0.72)>\mathrm{Na}(0.48)>\mathrm{Al}(0.47)>\mathrm{K}(0.40)$

$>\mathrm{Si}(0.38)>\mathrm{Ca}(0.37)>\mathrm{Cs}(0.20)>\mathrm{Au}(0.07)$
Elements not included in the above sequence because the element concentration data for the nodule are quoted as "greater than" are $\mathrm{Nb}(>3)$, $\mathrm{Zr}(>2), \mathrm{Pb}(>1.7)$ and $\operatorname{Sr}(>1.5)$.

This element enrichment sequence is very similar to that observed for the G1004c nodule/ G1003 sediment pair (although the enrichment values are slightly different due chiefly to the different sediment composition). In addition, the sequence is not too dissimilar from those calculated from the data of LANDMESSER et al. (1976) and CALVERT and PRICE (1977) or of BONATTI et al. (1971) for elements enriched by diagenesis in the upper layers of sediment cores relative to lower horizons. Differences indicate that this sequence is, however, not uniform from place to place.

A striking feature of the element enrichment sequence is the marked enrichment of $\mathrm{Tl}$ in the nodules relative to surrounding sediment. The alkali metals and alkaline earths, the elements associated with the silicate phase, together with $\mathrm{Pd}$ and $\mathrm{Au}$, on the other hand, constitute the elements least enriched in nodules relative to sediments. It is interesting that the two noble metals, $\mathrm{Au}$ and Ir, lie at either end of the enrichment sequence; this may be due to their markedly different abilities to form complex ions and the relative stabilities of these complexes in different redox environments.

Comparison of the rare earth distribution in nodules with that in the underlying sediments (Fig. 1) shows that nodules at Stn 994 has higher rare earth element enrichment than that observed at Stn G1004c. This may be due to the fact that while the rare earth contents of the nodules are relatively constant throughout the Southwestern Pacific Basin, sediment composition is affected by the input of terrigenous sediment as discussed previously. This would have the effect of decreasing the rare earth contents of nodules relative to sediments in the Southwestern Pacific Basin with increasing distance from the New Zealand landmass. Alternatively, the sediments may contain differing proportions of micronodules. The presence of micronodules in sediments would decrease the observed rare earth element enrichment. The similarity of the shape of the shale-normalised curves for nodules and sediments suggests the possibility of incorporation of ferromanganese material. 


\section{Discussion}

A striking feature of the data is the similarity in trace element concentrations in nodules from two sites $258 \mathrm{~km}$ apart in the Southwestern Pacific Basin. This suggests that variations in trace element compositions of nodules within individual deep-sea basins are likely to be small where sediment composition changes are not marked. Future studies of such variations should therefore only be carried out using very precise analytical techniques. The similarity in trace element composition of the nodules in this basin is probably a reflection of their major element composition. In addition, the similarity in composition of nodules from the Southwestern Pacific Basin where red clay is the dominant sediment type to the nodules (6269) from the Carlsberg Ridge, Indian Ocean, where globigerina ooze is the dominant sediment type, suggests that sediment type per se is not the major factor controlling the trace element composition of deep-sea nodules. Since all samples studied here contain $\delta \mathrm{MnO}_{2}$ as the principal manganese oxide material, manganese oxide mineralogy is clearly not a major factor in controlling difference in composition of these nodules (c.f. Calvert and Price 1977; Calvert et al. 1978). However, the higher silicate mineral content of Z2140 from north of the Indian-Antarctic Ridge may explain the lower rare earth element abundance of this particular nodule. A further factor controlling the content of trace elements in nodules is nodule growth rate (e.g. HEYE and Marchig 1977; PIPER and Williamson 1977). PIPER and WILliamson (1977), for example, have shown that $\mathrm{Mn} / \mathrm{Fe}$ ratios of nodules are related to nodule growth rate. However, the four deepsea nodules studied in this paper all have $\mathrm{Mn} / \mathrm{Fe}$ ratios close to unity (with a range of 1.7 ) which in some cases is somewhat less than that shown by the minor elements. This suggests that variations in nodule growth rate are not the only factor in controlling trace element composition.

The relationship between the element concentration in nodules and their underlying sediments is very similar for Stns G994 and G1004c. This relationship is linear (Fig. 3 ) as has been shown by GlaSbY (1975) using mean data from diverse sources in the literature (GLASBY 1975, p.134 Fig. 2). Several other authors have also pointed to a relationship between the element composition of deep-sea manganese nodules and their associated pelagic sediments (e.g. RILEY and Chester 1971; Elderfield 1972; Chester et al. 1973; see also CHESTER and AsTON 1976;

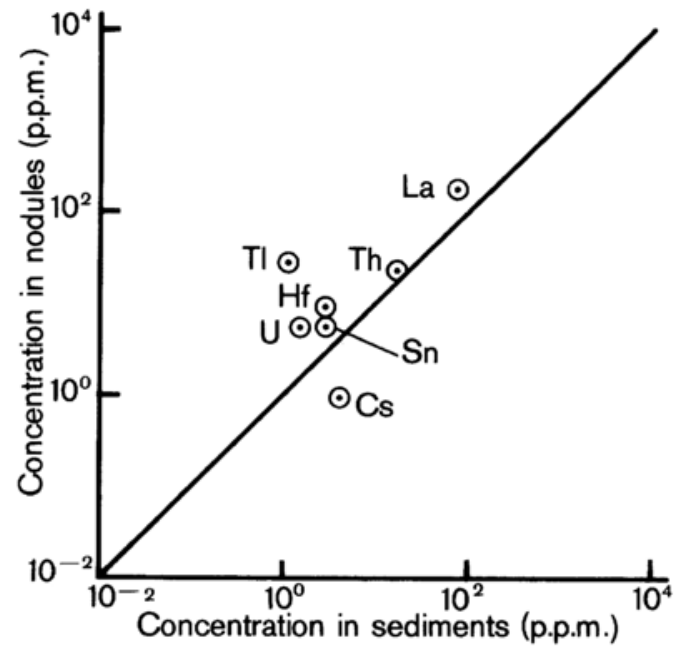

Fig. 3. Relationship between element composition of nodule and the underlying sediment at Station G994.

Elderfield 1976). The trend reported here supports the idea of a similar mode of incorporation of elements into manganese nodules and their associated sediments in a region as the Southwestern Pacific Basin where red clay forms the dominant sediment type. The enrichment sequence of elements shows that $\mathrm{Tl}$ is the most enriched in nodules relative to the underlying sediment (also noted by GLASBY, 1975) and Cs and $\mathrm{Au}$ are the least enriched, possibly because of their association with clay minerals in the marine sediments.

The fossil nodule from Timor appears to be anomalous in composition. Weathering during the extremely long period of exposure on land may have resulted in some loss of the more mobile elements from the nodule. This view is supported by the recent work of JOHNSTON and GlasbY (1978) using Mössbauer spectroscopy which has shown that recrystallisation of the iron oxide phase of the Timor nodule has taken place since the nodule was exposed and this may have led to some element redistribution. In spite of this, the trace element composition can be recognised as being typical of that of a deep-sea nodule.

Few studies have been made on the variation of rare earth elements in nodules within a given ocean. In a publication by VolKov and FomINA (1973), it was established that the total rare earth content of Pacific Ocean nodules increases with increasing distance from land and is correlated with the iron and manganese contents of the nodules (c.f. Volkov et al. 1975). Replott- 


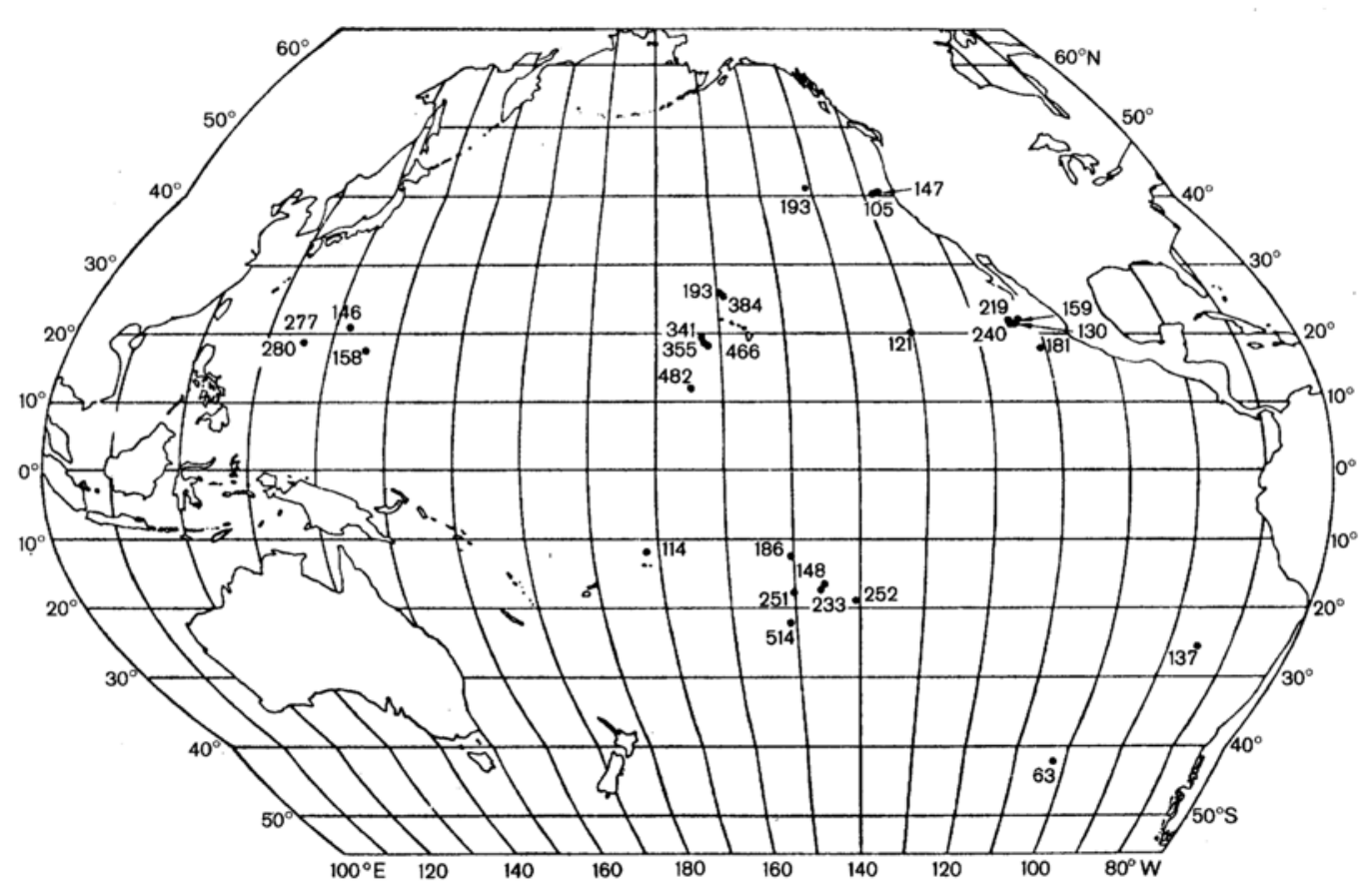

Fig. 4. Relationship in deep-sea nodules of La content (representing total rare earth content) and geographic location of station from which nodules were obtained (data from PIPER 1974a).

ing the La contents (as a measure of $\Sigma$ R.E.E.) of Pacific Ocean nodules obtained by PIPER (1974) on a geographic basis (Fig. 4) lends some support to this observation; lowest $\mathrm{La}$ values (in the range $100-200 \mathrm{ppm}$ ) are found at the margins of the Pacific Basin whilst highest values (up to $500 \mathrm{ppm}$ ) are found in the deep-ocean basins far from land. The data of SHIMOKAWA et al. (1972) show similar features. This trend is, however, not entirely consistent and there appears to be no direct correlation of the $\mathrm{La}$ content with water depth in Pacific Ocean nodules (Fig. 5) indicating that depth per se is not a major factor in controlling the total rare earth content in nodules. By contrast, a relationship between the $U$ and $T h$ contents of manganese nodules and water depth has been suggested by a number of workers (e.g. Ku and BROECKER 1969; Mo et al. 1973; MARGOLIS et al. 1978) (see also Sugimura et al. 1975; KUnZENDORF and F RIEDRICH 1976a, b, 1977; KORKISCH et al. 1977). The nodules analysed here display $\mathrm{U}$ and $\mathrm{Th}$ values typical of those obtained for deep-sea nodules by these authors. The $U$ and $\mathrm{Th}$ concentrations of marine sediments and basalts have been presented by HEYE (1969), Boström: and Fisher (1971), TUREKIAN and BERTINE (1971), MacDougall (1977) and Mitchell and Aumento (1977). The origin of the geographic variation in the total rare earth contents of Pacific Ocean nodules is not understood but may be related to diagenetic processes similar to those outlined by PRICE and CALVERT (1970), Horn et al. (1972) and Glasby (1975) (c.f. Calvert and Price 1977; PIPER and Williamson 1977; Calvert et al. 1978). It should be emphasised, however, that whilst VoLKOV and FOMINA (1973) found a relationship between the total rare earth contents of Pacific Ocean nodules and the manganese and iron contents of the nodules, no similar correlation between the rare earth element content and either the manganese or iron contents was found in the 5 nodules studied in this paper. RANKIN and CHILDS (1976) found a positive correlation between the total rare earth element content and $\mathrm{Mn}$ (but not $\mathrm{Fe}$ ) for nodules formed in New Zealand soils.

The distribution of $\mathrm{Tl}, \mathrm{Ir}, \mathrm{Pd}$ and rare earth elements between deep-sea manganese nodules and their associated sediments appears to be strongly influenced by a number of factors, including the major element composition of the nodules, the differing stability of the various complexes of the elements, and the difference in redox state between the nodules and the sediments.

The silica contents of the nodules would 


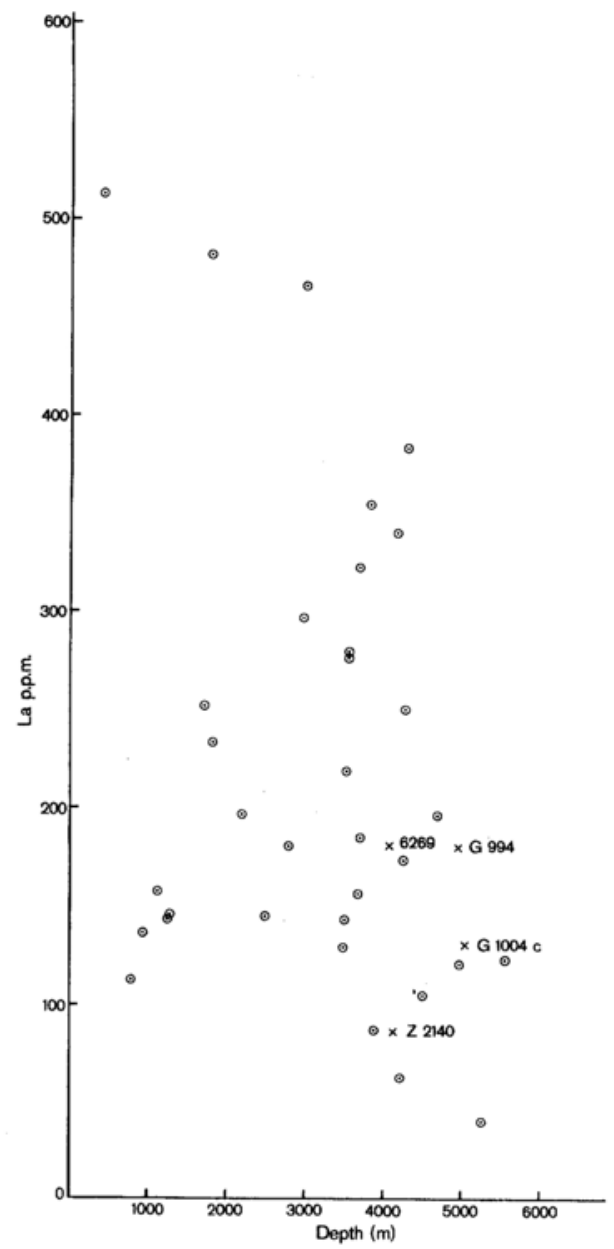

Fig. 5. Relationship in deep-sea nodules of La content (representing total rare earth content) and depth (data from PIPER 1974a).

appear to be particularly important in the control of the distribution of Tl, Ir, Pd and rare earths. This contradicts the observations of HARRISs et al. (1968) that no correlation exists between variations in the precious metal and major element content. A positive relationship between $\mathrm{Au}$ and silica for both nodules and associated sediments is suggested by Fig. 6 and this can be interpreted to indicate that $\mathrm{Au}$ is not adsorbed onto authigenic ferromanganese oxide phases but is incorporated with the detrital silicate minerals and authigenic clays. This interpretation is supported by the fact that the two red clay sediments (G994, G1003) contain a factor of ten more $\mathrm{Au}$ than the associated nodules (Table 2). CROcket et al. (1973) have argued that the detritus contributed to the marine environment will not differ in $\mathrm{Au}, \mathrm{Pd}$ or Ir content compared to its continental source

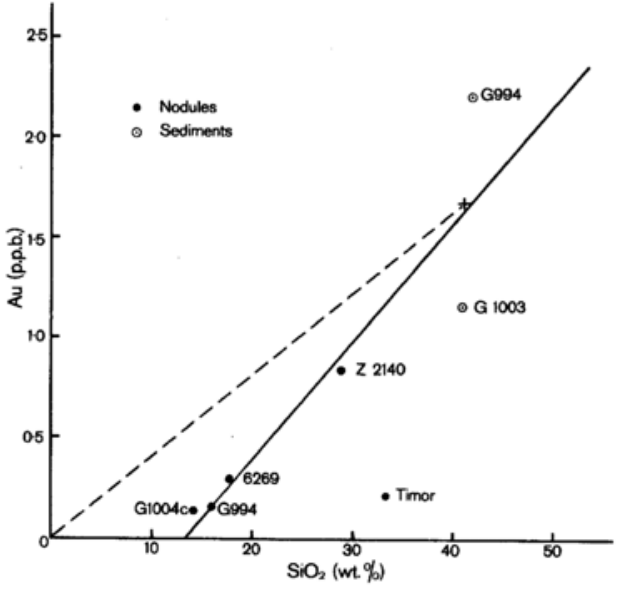

Fig. 6. Positive correlation between the $\mathrm{Au}$ and $\mathrm{SiO}_{2}$ contents of deep-sea nodules and red clay sediments. The dashed line represents a mixing curve between detritus containing 17ppb $\mathrm{Au}$ (the average $\mathrm{Au}$ content of the sediments) and an authigenic $\mathrm{Fe}-\mathrm{Mn}$ component containing no $\mathrm{Au}$ or $\mathrm{SiO}_{2}$. Note that all of the nodules contain significantly less $\mathrm{Au}$ than that which they would have contained if formed by simple mixing of these two end members. The low Au content of the Timor nodule suggests that it contained much less silica before obduction.

rocks, and some of the $\mathrm{Au}$ will therefore be incorporated in the detrital material. If the detrital material in the nodules contributed the same amount of Au to the nodules as it does to the underlying sediments (average Au content $=1.7 \mathrm{ppb}$ ) and if its silica content is the same as that of the sediments, then it should be possible to calculate the amount of $\mathrm{Au}$ contributed to the nodules by the detrital material. Clearly, the nodules contain much less $\mathrm{Au}$ than that which would have been contributed by detritus (Fig. 6). In the case of nodule G994 with a silica content of $15.8 \%, 0.64 \mathrm{ppb} \mathrm{Au}$ would have been contributed by detritus whereas the nodule contains only $0.16 \mathrm{ppb} \mathrm{Au}$. Hence, $0.48 \mathrm{ppb} \mathrm{Au}$ is unaccounted for in the nodule. The explanation may be that some of the Au contributed with the detritus (perhaps Au contributed by organic particles which are believed by HuMMEL (1957) to be a significant carriers of $\mathrm{Au}$ in the marine environment) was solubilized in the environment of the manganese nodules.

Gold contributed by detritus to the deep-sea sediments will encounter a low redox environment (Eh c. $0.05 \mathrm{v}$ ) at a depth of $50 \mathrm{~cm}$ whereas that contributed to the manganese nodules will be subjected to a much higher oxidation poten- 
tional (Eh in excess of 0.65 and possibly as high as 0.80v) (CRERAR and BARNES 1974). Gold contributed to the sediments is likely to remain as a solid, probably metallic $\mathrm{Au}$, while part of that added to the nodules may form complex ions. At a $\mathrm{pH}$ of 7.5 , the approximate $\mathrm{pH}$ of deep ocean waters (PARK 1968), $\mathrm{AuCl}_{4}^{-}$is the most stable complex of $\mathrm{Au}$ in seawater (BAes and Mesmer 1976) (cf. Crocket 1974). Gold leached from the manganese nodule as $\mathrm{AuCl}_{4}{ }^{-}$(or any other complex ion) may then be added either to the surrounding seawater or to the underlying sediments where it would precipitated because of their low redox state.

The Timor nodule is anomalous in the relationship between $\mathrm{Au}$ and silica contents (Fig. 6). Its $\mathrm{Au}$ content (and its high Ir content) would suggest that the nodule originally contained less than $16 \% \mathrm{SiO}_{2}$. This agrees with the findings of MARGolis et al. (1978) that the present high silica content $(33 \%)$ may reflect the diagenetic loss of manganese from the nodule during exposure on land.

The inverse correlations of $\mathrm{Ir}, \mathrm{Tl}$ and the rare earths with silica content (see Fig. 7 for Ir/silica data) can be explained to different degrees by

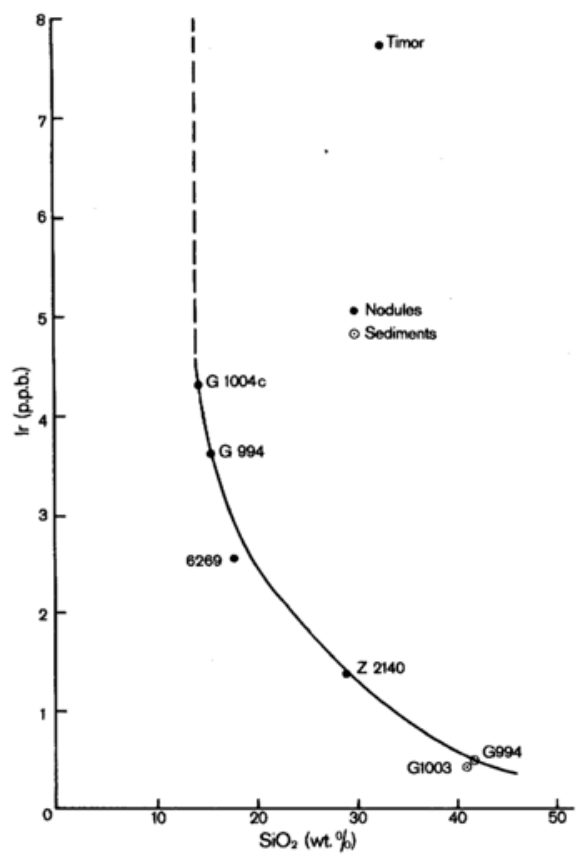

Fig. 7. Negative correlation between Ir and silicacontents of deep-sea nodules and red clay sediments. The high Ir content of the Timor nodule confirms that it is an obducted deep-sea nodule that originally contained about 15 wt. per cent silica. dilution of the ferromanganese oxide phase by silicate minerals. Most of the variations in the rare earth contents of the nodules can be interpreted in terms of simple dilution by silicate minerals. The rare earths are preferentially incorporated into the nodules due to hydrolysis under oxidising conditions. Dilution by silicates does not account for all the variation observed in the content of Ir and Tl. An additional factor in the case of Ir may be the growth rate of the nodules while the marked variation of $\mathrm{Tl}$ with silica content may be influenced by variations in redox state. $\mathrm{Tl}^{+}$is stable in acid and alkaline aqueous solutions whereas $\mathrm{Tl}^{3+}$ is stable only in solutions of low $\mathrm{pH}$, forming the very insoluble thallic hydroxide precipitate when solutions of $\mathrm{Tl}^{3+}$ are made basic (PETERSON 1962). It is therefore possible that $\mathrm{Tl}$ goes into solution as $\mathrm{Tl}^{+}$in the low oxidizing environment of the sediments whereas in the ferromanganese nodules it is oxidized to $\mathrm{Tl}^{3+}$ and precipitated as $\mathrm{Tl}(\mathrm{OH})_{3}$.

The reason for the low enrichment of many elements in the nodules relative to the sediments may be the ability of the elements to form stable complexes in seawater which inhibit the incorporation of these elements into the nodules. In the case of Au it may be chloro complexes, as stated above, whereas carbonate complexes may be important in the case of $\mathrm{U}$ and $\mathrm{Pb}$ (see (AHrLAND 1975; Brewer 1975; StUMm and BRAUNER 1975; LONG and ANGINo 1977; VAN DER WEIJDEN and KRUISSINK 1977). Among the elements most enriched in nodules relative to sediments, $\mathrm{Tl}, \mathrm{Zr}$, Th, $\mathrm{Ti}$ and $\mathrm{Sn}$ exist in the forms $\mathrm{Tl}^{+}, \mathrm{Zr}(\mathrm{OH})_{4}^{\circ}, \mathrm{Th}(\mathrm{OH})_{4}^{\circ}, \mathrm{Ti}(\mathrm{OH})_{4}^{\circ}$ and $\mathrm{SnO}(\mathrm{OH})_{3}^{-}$ respectively (BREWER 1975). From the data of LANDMESSER et al. (1976), niobium (which is probably present in seawater in the particulate form), molybdenum $\left(\mathrm{MoO}_{4}^{2-}\right)$, and tungsten $\left(\mathrm{WO}_{4}^{2-}\right)$ are in this category (BAES and MESMER 1976 , p.249). It therefore appears that complex formation in the seawater has a marked effect in controlling the enrichment of elements in nodules by inhibiting adsorption or coprecipitation of complexed species. The low contents of $\mathrm{Re}$ and $\mathrm{Cr}$ in nodules may, however, reflect formation of stable anionic species in this seawater (GLASBY 1973) which may not be readily taken up into nodules.

Acknowledgements-Mr. M. T. HAUKKA (University of Melbourne) is thanked for the X.R.F. determinations; these were subsequently confirmed by Mr. J. L. HUNT (Soil Bureau). Mr. P. HANNAKER (University of 
Melbourne) is thanked for the atomic absorption, $\mathrm{H}_{2} \mathrm{O}^{+}$ and $\mathrm{CO}_{2}$ determinations; The $\mathrm{CO}_{2}$ determinations were confirmed by Mr. L. C. BLAKEMORE (Soil Bureau) using the Leco method. Mr. G. ATKINS assisted with the neutron activation analyses. Dr. P. J. POTTS and M. SARRE (Open University) carried out neutron activation analysis of rare earths in the Timor nodule. A. J. FLEET (Open University) gave permission to quote rare earth data from a second Timor nodules. This research was supported in part by an Australian Institute of Nuclear Science Engineering grant to R.R.K. Drs. J. L. BISCHOFF, J. H. CROCKET, and H. W. NESBITT are thanked for their useful comments on the manuscript.

\section{REFERENCES}

AHRLAND, S. (1975) Metal complexes present in seawater. The nature of seawater, E. D. GOLDBERG, (Ed.) Dahlem Workshop Report, Berlin, 219-244.

ANON (1974) Manganese deposits. in Hawaii and the sea. State of Hawaii Department of Planning and Economic Development. 7-5, 7-10.

AUDLEY-CHARLES, M. (1972) Cretaceous deep-sea manganese nodules on Timor: Implications for tectonics and olistostrome development. Nature Phys. Sci. 240, 137-139.

BAES, C. F. and MESMER, R. E. (1976) The hydrolysis of cations. John Wiley \& Sons, N.Y.

BäCKER, H., Glasby, G. P., MEYlan, M. A.(1976) Manganese nodules from the Southwestern Pacific Basin. NZOI Oceanogr. Fld Rep. 6, 88 pp.

BALASHOV, YU. A., TURANSKAYA, N. V. and BRATISHKO, R. KH. (1974) Zoning of the rareearth element distribution in oceans. Geokhimiya No. 5, 751-762.

BARKER, J. L. and ANDERS, E. (1968) Accretion rate of cosmic matter from iridium and osmium contents of deep-sea sediments. Geochim. cosmochim. Acta 32, 627-645.

BISCHOFF, J. L. and PIPER, D. A. (1976) Chemical composition of marine sediments of DOMES Site C. in Deep ocean mining environmental study, NE Pacific Nodule Province, Site C, geology anà geochemistry, J. L. BisCHOFF and others, (Compilers), U. S. Geol. Surv. Open-File Rep. 76-568, 113-130.

BISCHOFF, J. L. and PIPER, D. Z. (1977) Chemical composition of marine sediments at DOMES Sites A \& B. in D. Z. PIPER (Compiler) Deep ocean environmental study: Geology and geochemistry of DOMES Sites $A, B$ and $C$, equatorial North Pacific. U.S. Geol. Surv. Open-File Report 77-778, 119145.

BonatTi, E., Fisher, D. C., Joensusu, O. and RYdell, H. S. (1971) Postdepositional mobility of some transition elements, phosphorus, uranium and thorium in deep sea sediments. Geochim. Cosmochim. Acta 35, 189-201.

BOSTRÖM, K. and FISHER, D. E. (1971) Volcanogenic uranium, vanadium and iron in Indian Ocean sediments. Earth Planet. Sci. Lett. 11, 95-98.

BREWER, P. G. (1975) Minor elements in sea water. in Chemical oceanography, 2nd Ed., vol. 1. J. P. RILEY and G. SKIRROW (Eds.) Academic Press, London. 415-496.

Calvert, S. E. and Price, N. B. (1977) Geochemical variation in ferromanganese nodules and associated sediments from the Pacific Ocean. Mar. Chem. 5, 43-74.

Calvert, S. E., Price, N. B., Heath, G. R. and MOORE, T. C. (1978) Relationship between ferromanganese nodule compositions and sedimentation in a small survey area of the equatorial Pacific. $J$. Mar. Res. 36, 161-183.

Chester, R. and ASTON, S. R. (1976) The geochemistry of deep-sea sediments. in Chemical oceanography, 2nd Ed., vol. 6. J. P. RILEY and R. CHESTER (Eds.) Academic Press, London. 281-390.

CHESTER, R., Johnson, L. R., MESSIHA-HANNA, R. G. and PADGHAM, R. D. (1973) Similarities between $\mathrm{Mn}, \mathrm{Ni}$ and Co contents of deep-sea clays and manganese nodules from the south-west region of the North Atlantic. Mar. Geol. 14, M15-M20.

Crerar, D. A. and Barnes, H. L. (1974) Deposition of deep-sea manganese nodules. Geochim. Cosmochim. Acta 38, 279-300.

Crocket, J. H. (1969) Platinum metals. in Handbook of geochemistry, Vol. II-1. Chap. 78 K. H. WEDEPOHL, (Ed.) Springer-Verlag, Berlin.

CROCKET, J. H. (1974) Gold. in Handbook of geochemistry, Vol.II-4. Chap. 79 K. H. WEDEPOHL, (Ed.) Springer-Verlag, Berlin.

CRocket, J. H., KeAYS, R. R. and HSIEH, S. (1968) Determination of some precious metals by neutron activation analysis. J. Radioanal. Chem. 1, 487-507.

CROCKet, J. H., MACDOUgall, J. D. and Harriss, R. C. (1973) Gold, palladium, and iridium in marine sediments. Geochim. Cosmochim. Acta 37, 2547-2566.

Crocket, J. H. and Teruta, Y. (1977) Palladium, iridium, and gold contents of mafic and ultramafic rocks drilled from the Mid-Atlantic Ridge, Leg 37, Deep Sea Drilling Project. Can J. Earth Sci. 14, 777-784.

De Albuquerque, C. A. R. and Shaw, D. M. (1972) Thallium. in Handbook of geochemistry, Vol. II-3. Chap. 81 K. H. WEDEPOHL (Ed.) Springer-Verlag, Berlin.

Dymond, J., CoRliss, J. B., HeATH, G. R., Field, C. W. DASCH, E. J. and VEEH, H. H. (1973) Origin of metalliferous sediments from the Pacific Ocean. 
Bull. Geol. Soc. Am. 84, 3355-3372.

ELDERFIELD, H. (1972) Compositional variations in the manganese oxide component of marine sediments. Nature Phys. Sci. 237, 110-112.

ELDERFIELD, H. (1976) Hydrogenous material in marine sediments: excluding manganese nodules. in Chemical oceanography, 2nd Ed., Vol. 5. J. P. RILEY and R. CHester (Eds.) Academic Press, London. 137-215.

El WAKeEL, S. K. and RILeY, J. P. (1961) Chemical and mineralogical studies of deep-sea sediments. Geochim. Cosmochim. Acta 25, 110-146.

Flanagan, F. J. (1973) 1972 values for international geochemical reference standards. Geochim. Cosmochim. Acta 37, 1189-1200.

FLEET, A. J. (1975) Rare earth fractionation in the marine environment, in The determination and interpretation of rare earth abundances in rocks and minerals. Scottish Universities Research and Reactor Centre, East Kilbride (Abstract).

FLEET, A. J. (1977) Geochemistry of drilled (DSDP) sediments from the southern Indian Ocean. Unpubl. $\mathrm{Ph}$. D. thesis (Univ. London). $369 \mathrm{pp}$.

Fleet, A. J. HENDERSON, P. and Kempe, D. R. C. (1976) Rare earth element and related chemistry of some drilled southern Indian Ocean basalts and volcanogenic sediments. J. Geophys. Res. 81, 42574268.

FLeET, A. J. and KeMPE, D. R. C. (1974) Preliminary geochemical studies of the sediments from DSDP Leg 26, southern Indian Ocean. in Initial reports of the deep sea drilling project, Vol. 26. U.S. Govt. Printing Office, Washington, D.C. 541-551.

GlaSBY, G. P. (1972a) Manganese deposits in the Southwest Pacific. Hawaii Inst. Geophys. Rep. HIG$72-73,59-82$.

GLASBY, G. P. (1973) Mechanisms of enrichment of the rarer elements in the marine manganese nodules. Mar. Chem. 1, 105-125.

GlaSBY, G. P. (1.975) Minor element enrichment in manganese nodules relative to seawater and marine sediments. Naturwissenschaften 62, 133-135.

Glasby, G. P., TOOMS, J. S. and Howarth, R. J. (1974) Geochemistry of manganese concretions from the northwest Indian Ocean. N. Z. Jl. Sci. 17, 387-407.

GoLDBERG, E. D. (1965) Minor elements in sea water. in Chemical oceanography, Vol. 1. J. P. RILEY and R. CHESTER (Eds.) Academic Press, London. 163-196.

GoldBerG, E. G. and ARrheniUS, G. O. S. (1958) Chemistry of Pacific pelagic sediments. Geochim. Cosmochim. Acta 13, 153-212.

GoldberG, E. D., KoIDE, M., SChMitT, R. A. and SMITH, R. H. (1963) Rare earth distribution in the marine environment. J. Geophys. Res. 68, 4209-
4217.

Harriss, R. C., Crocket, J. H. and Stainton, M. (1968) Palladium, iridium, and gold in deep-sea manganese nodules. Geochim. Cosmochim. Acta 32, 1049-1056.

HASKIN, L. and GEHL, M. A. (1962) The rare-earth distribution in sediments. J. Geophys. Res. 67, 2537-2541.

HASKIN, L. A. and SCHMITT, R. A. (1967) Rare-earth distributions. in Researches in geochemistry, Vol. 2. P. H. ABELSON (Ed.) John Wiley \& Sons, N.Y. 234258.

Haskin, L. A., Wildeman, T. R., Frey, F. A., Collins, K. A., KeEdY, C. R. and HASKIN, L. A. (1966) Rare earths in sediments. J. Geophys. Res. 71, 6091-6105.

HEIN, J. R.; YEH, H.-W.; AleXANDER, E. R. (In press) Distribution, mineralogy, chemistry and oxygen isotopes of clay minerals from the north equatorial Pacific manganese nodule belt. Proc. 6th Internat. Clay Conf., Oxford. Elsevier, Amsterdam.

HERRMANN, A. G. (1970) Yttrium and lanthanides. in Handbook of geochemistry, Vol. II-2, Chap. 39 K. H. WEDEPOHL (Ed.) Springer-Verlag, Berlin.

HEYE, D. (1969) Uranium, thorium, and radium in ocean water and deep-sea sediments. Earth Planet. Sci. Lett. 6, 112-116.

HEYE, D. and MARCHIG, V. (1977) Relationship between the growth rate of manganese nodules from the central Pacific and their chemical constitution. Mar. Geol. 23, M19-M25.

HORN, D. R., HORN, B. M. and DELACH, M. N. (1972) .Ferromanganese deposits of the North Pacific. Tech. Rep. Off Int. Decade Ocean Exlor. 1, $78 \mathrm{pp}$.

HUMMEL, R. W. (1957) Determination of gold in seawater by radioactivation analysis. Analyst, Lond. 82, $483-488$.

Johnston, J. H. and Glasby, G. P. (1978) The secondary iron oxidehydroxide mineralogy of some deep-sea and fossil manganese nodules: A Mössbauer and X-ray study. Geochem. J. 12, 153-164.

Keays, R. R., Ganapathy, R., Laul, J. C., KRAHENBUHL, U. and MORGAN, J. W. (1974) The simultaneous determination of 20 trace elements in terrestrial, lunar, and meteoritic material by radiochemical neutron activation analysis. Anal. Chim. Acta 72, 1-29.

KeAYS, R. R. and SCOTT, R. B. (1976) Precious metals in ocean-ridge basalts: Implications for basalts as source rock for gold mineralisation. Econ. Geol. 71, 705-720.

Korkisch, J., Steffan, I., ARRHENiUs, G. Fisk, M. and FraZER, J. (1977) Chemical analysis of manganese nodules Part II. Determination of uranium 
and thorium after anion - exchange separation. Anal. Chim. Acta 90, 151-158.

KU, T-L. and BROECKER, W. S. (1969) Radiochemical studies on manganese nodules of deep-sea origin. Deep-sea Res. 16, 625-637.

KUNZENDORF, H. and FRIEDRICH, G. H. (1976a) Uranium and thorium in deep-sea manganese nodules from the central Pacific. Trans. Instn. Min. Metall. 85B, 284-288.

KUNZENDORF, H. and FRIEDRICH, G. H. W. (1976b) The distribution of $U$ and $T h$ in growth zones of manganese nodules. Geochim. Cosmochim. Acta 40, $849-852$.

KUNZENDORF, H. and FRIEDRICH, G. (1977) Die Verteilung von Uran in Manganknollen in Abhängigkeit von der Knollenfazies und der Morphologie des Meeresbodens. Erzmetall. 30, 590-592.

LANDMESSER, C. W., KROENKE, L. W., Glasby, G. P., SAWTell, G. H., Kingan, S., Utanga, E. and CowAN, G. (1976) Manganese nodules from the south Penrhyn Basin, Southwest Pacific. South Pacific Mar. Geol. Notes 1 (3), 17-39.

LONG, D. T. and ANGINo, E. E. (1977) Chemical speciation of $\mathrm{Cd}, \mathrm{Cu}, \mathrm{Pb}$, and $\mathrm{Zn}$ in mixed freshwater, seawater, and brine solutions. Geochim. Cosmochim. Acta 41, 1183-1191.

LOVERING, J. F. and BUTTERFIELD, D. (1970) Neutron activation analysis of rhenium and osmium in Apollo II lunar material. Proceed. Apollo II Lunar Science Conf., Vol. 2, Geochim. Cosmochim. Acta, Suppl. 1, Vol. 34, 1351-1355.

MACDOUGALL, J. D. (1977) Uranium in marine basalts: Concentration, distribution and implications. Earth Plant. Sci. Lett. 35, 65-70.

Margolis, S. V., KU, T. L., Glasby, G. P. Fein, C. D. and AUdLEY-CHARLES, M. G. (1978) Fossil manganese nodules from Timor: Geochemical and radiochemical evidence for deep-sea origin. Chem. Geol. 21, 185-198.

Martin, J.-M., H $\phi$ GDAHL, O. and PhillpotT, J. C. (1976) Rare earth element supply to the ocean. $J$. Geophys. Res. 81, 3119-3124.

MASUDA, A. and NAGASAWA, S. (1975) Rocks with negative cerium anomalies, dredged from Shatsky Rise. Geochem. J. 9, 227-233.

Melguen, M., Debrabant, P., Chamley, H., MAIllot, H., HOFFerT, M. and Courtols, C. (In press) Influence des courants profonds sur les facies sedimentaires du Vema Channel (Atlantique Sud) a la fin du Cenozoique. Bull. Soc. Géol. Fr.

MEYLAN, M. A., BÄCKER, H. and GLASBY, G. P. (1975) Manganese nodule investigations in the Southwestern Pacific Basin, 1974. NZOI Oceanogr. Fld. Rep. 4, $22 \mathrm{pp}$.

MitchelL, W. S. and Aumento, F. (1977) Uranium in oceanic rocks, DSDP Leg 37. Can. J. Earth Sci. 14, 794-808.

Mo, T., SutTle, A. D. and SACKeTt, W. M. (1973) Uranium concentrations in marine sediments. Geochim. Cosmochim. Acta 37, 35-57.

NOAKES, L. C. and JONES, H. A. (1975) Mineral resources off-shore. in Economic geology of Australia and Papua New Guinea 1. Metals. C. L. KNIGHT (Ed.) Australasian Institute of Mining and Metallurgy, Parkville, Australia. 1093-1140.

NORRISH, K. and HUTTON, J. T. (1969) An accurate $\mathrm{X}$-ray spectrographic method for the analysis of a wide range of geological samples. Geochim. Cosmochim. Acta 33, 431-453.

PARK, P. K. (1968) Seawater hydrogen ion concentrations: Vertical distributions. Sci., N.Y. 162, 357358.

PETERSON, J. I. (1962) Thallium. in Comprehensive analytical chemistry, Vol. 1. C.L. WILSON and D.W. WILSON (Eds.) Elsevier, Amsterdam. 130-139.

PIPER, D. Z. (1972) Rare-earth elements in manganese nodules from the Pacific Ocean, in Ferromanganese deposits on the ocean floor. D. R. HORN (Ed.) National Science Foundation, Washington D.C., 123-130.

PIPER, D. Z. (1973) Rare-earth elements in ferromanganese nodules and other marine phases, in InterUniversity program of research on ferromanganese deposits of the ocean floor phase I report. National Science Foundation, Washington, D.C., 7-21.

PIPER, D. Z. (1974a) Rare earth elements in ferromanganese nodules and other marine phases. Geochim. Cosmochim. Acta 38, 1007-1022.

PIPER, D. Z. (1974b) Rare earth elements in the sedimentary cycle: A summary. Chem. Geol. 14, 285-304.

PIPER, D. Z. and Graef, P. A. (1974) Gold and rare-earth elements in sediments from the East Pacific Rise. Mar. Geol. 17, 287-297.

PIPER, D. Z., VeEH, H. H., Bertrand, W. G. and ChASE, R. L. (1975) An iron-rich deposit from the Northeast Pacific. Earth Planet. Sci. Lett. 26, 114-120.

PIPER, D. Z. and WiLliamson, M. E. (1977) Composition of Pacific Ocean ferromanganese nodules. Mar. Geol. 23, 285-303.

Price, N. B. and Calvert, S. E. (1970) Compositional variation in Pacific Ocean ferromanganese nodules and its relationship to sediment accumulation rates. Mar. Geol. 9, 145-171.

RAAB, (1972) Physical and chemical features of Pacific deep-sea manganese nodules and their implications to the genesis of nodules, in Ferromanganese deposits on the ocean floor, D. R. HORN (Ed.) National Science Foundation, Washington, D.C. 31- 
49.

Rankama, K. and Sahama, T. H. G. (1950) Geochemistry. The University of Chicago Press, Chicago.

RANKIN, P. C. and CHILDS, C. W. (1976) Rare-earth evidence in iron-manganese concretions from some New Zealand soils. Chem. Geol. 18, 55-74.

RANKIN, P. C. and GlaSBY, G. P. (In press) Regional distribution of rare earth and minor elements in manganese nodules and associated sediments in the Southwest Pacific and other localities. in Marine geology and oceanography in the central Pacific manganese nodule province. J. L. BISCHOFF and D. Z. PIPER (Eds.) Pergamon Press.

RILEY, J. P. and CHESTER, R. (1971) Introduction to marine chemistry. Academic Press, London.

ShaW, D. M., Dostal, J. and KeaYs, R. R. (1976) Additional estimates of continental surface Precambrian shield composition in Canada. Geochim. Cosmochim. Acta 40, 73-83.

Shilo, N. A., RAZIN, L. V., KhomenKo, G. A. and AGALTSOV, G. I. (1977) On the modes of occurrence of gold and palladium in oceanic abyssal ferromanganesian concretions. Dokl. Akad. nauk SSSR 232, 466-469 (In Russian).

SHIMA, M. (1974) Manganese nodules. Chemistry Today No. 42, 32-42 (In Japanese).

Shimokawa, T., Masuda, A. and IZaWA, K. (1972) Rare-earth elements in the top samples of the cores from the Pacific Ocean floor. Geochem. J. 6, 75-81.

Stumm, W. and Brauner, P. A. (1975) Chemical speciation. in Chemical oceanography, 2nd Ed., Vol. 1. J. P. RILEY and G. SKIRROW (Eds.) Academic Press, London. 173-239.
Sugimura, Y., MiYaKe, Y. and Yanagawa, H.(1975) Chemical composition and the rate of accumulation of ferromanganese nodules in the western North Pacific. Pap. Meteorol. Geophys. 26 (2), 47-54.

Sugimura, Y. (1977) Recent Japanese contributions to marine chemistry. Oceanogr. Mar. Biol. A. Rev. $15,47-71$.

THOMAS, I. L. and HAUKKA, M. T. (1978) XRF determination of trace and major elements using a singlefused disc. Chem. Geol. 21, 39-50.

ThOMPSON, G., BRYAN, W. B., FreY, F. A. and DICKEY, J. S. (1978) Basalts and related rocks from Deep-sea Drilling sites in the central and eastern Indian Oceans. Mar. Geol. 26, 119-138.

TUREKIAN, K. K. and BERTINE, R. K. (1971) Deposition of molybdenum and uranium along the major ocean ridge systems. Nature, Lond. 229, 250-251.

VAN DER WEIJDEN, C. H. and KRUISSINK, E. C. (1977) Some geochemical controls on lead and barium concentrations in ferromanganese deposits. Mar. Chem. $5,93-112$.

VolKov, I. I. and Fomina, L. S. (1973) New data on the geochemistry of the rare earths in the ocean sediments. Geochem. Int. 10, 1178-1187.

Volkov, I. I., Rozanov, A. G. and Sokolov, V. S. (1975) Redox processes in diagenesis of sediments in the Northwest Pacific Ocean. Soil Sci. 119, 28-35.

WILdEMAN, T. R. and HASKIN, L. (1965) Rareearth elements in ocean sediments. J. Geophys. Res. 70, 2905-2910.

YouNG, E. J. (1954) Trace elements in recent marine clays. Bull. Geol. Soc. Am. 65, 1329 (Abstract). 